\title{
On several new or poorly-known Oriental Paradoxosomatidae (Diplopoda: Polydesmida), XXV
}

\section{О несколыких новых или плохоизученных ориенталыных Paradoxosomatidae (Diplopoda: Polydesmida), XXV}

\author{
S.I. Golovatch \\ С.И. Головач
}

Institute for Problems of Ecology and Evolution, Russian Academy of Sciences, Leninsky prospekt 33, Moscow 119071 Russia. E-mail: sgolovatch@yandex.ru

Институт проблем экологии и эволюции РАН, Ленинский проспект, 33, Москва 119071 Россия.

KEY WORDS: Diplopoda, Polydesmida, Paradoxosomatidae, taxonomy, new records, new species, Indonesia, Thailand, Laos, Taiwan, continental China.

КЛЮЧЕВЫЕ СЛОВА: Diplopoda, Polydesmida, Paradoxosomatidae, таксономия, новые находки, новые виды, Индонезия, Таиланд, Лаос, Тайвань, материковый Китай.

ABSTRACT. This contribution is devoted to new records of eight known species from Indonesia, Singapore, Laos, Taiwan or continental China, as well as to descriptions of seven new species: Spinaxytes typica sp.n., from Thailand, Tylopus longisetosus sp.n., T. hirsutus sp.n., T. subtuberculatus sp.n., T. jaegeri sp.n. and T. altmannae sp.n., all five from Laos, and $T$. nigromarginatus sp.n., from southern mainland China.

How to cite this article: Golovatch S.I. 2018. On several new or poorly-known Oriental Paradoxosomatidae (Diplopoda: Polydesmida), XXV // Arthropoda Selecta. Vol.27. No.4. P.261-277. doi: 10.15298/arthsel. 27.4.01

РЕЗЮМЕ. Это сообщение посвящено новым находкам восьми известных видов из Индонезии, Сингапура, Лаоса, Тайваня и материкового Китая, а также описаниям семи новых видов: Spinaxytes typica sp.n., из Таиланда, Tylopus longisetosus sp.n., T. hirsutus sp.n., T. subtuberculatus sp.n., T. jaegeri sp.n. и $T$. altmannae sp.n., все пять из Лаоса, и $T$. nigromarginatus sp.n., из южной части материкового Китая.

\section{Introduction}

This paper is devoted to new records of eight known species from Indonesia, Singapore, Thailand, Laos, Taiwan or continental China, as well as to descriptions of seven new species, one each from Thailand and mainland China, and further five from Laos. The bulk of the material reported below belongs to the Senckenberg Museum, Frankfurt a.M., Germany (SMF), with only a few duplicates retained for the collection of the Zoological Museum, State University of Moscow, Russia (ZMUM).

\section{Taxonomy}

Anoplodesmus saussurii (Humbert, 1865)

MATERIAL. 1 \% (SMF), Singapore, Margaret Drive, N 01'18'17.29”, E $103^{\circ} 48^{\prime} 11.31^{\prime \prime}, 29 \mathrm{~m}$ a.s.1., secondary forest, daytime, sieving, 22.VI.2013, leg. P. Jäger.

REMARK. This species has long been recorded as introduced to Singapore [Decker, Tertilt, 2012].

\section{Anoplodesmus spiniger Chen, Golovatch, Mikhaljova et Chang, 2010}

Figs 1-7.

MATERIAL. $13 \sigma^{7} \sigma^{7}, 6$ 우, 2 juv. (SMF), $1 \sigma^{7}$ (ZMUM), Taiwan, Sheding Nature Park, N 21 ${ }^{\circ} 57^{\prime} 25.97^{\prime \prime}$, E 120 49'13.29”, $200 \mathrm{~m}$ a.s.1., disturbed primary forest, limestones, leaf litter, daylight sieving, 26.VI.2013; $1 \mathrm{O}^{7}$ (SMF), Taiwan, Kenting, close to Howard Beach Resort, N 2156'17.63”, E 12048’31.85”, 24 m a.s.l., secondary forest, daytime, Winkler extraction, 24.VI.2013, all leg. P. Jäger.

REMARK. These samples fully agree with the original description [Chen et al., 2010] and, as they also come from the southern part of the island, they may well be considered as near-topotypes. New illustrations (Figs 1-7) are provided to document the species identity, in particular the presence of a marked tooth (z) on the solenophore (Fig. 6).

Antheromorpha paviei (Brölemann, 1896)

MATERIAL. 1 O $^{1}$ (SMF), Laos, Champasak Prov., $2.5 \mathrm{~km} \mathrm{~S}$ of

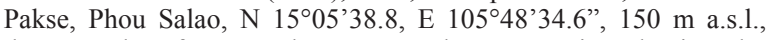
dry secondary forest, under stones and on vegetation, daytime, by hand, 7-15.XI.2012, leg. P. Jäger.

REMARKS. This species is widespread in Thailand, also recorded from the southern parts of Vietnam and Laos [Likhitrakarn et al., 2016a; Nguyen et al., 2018]. The above $\mathrm{O}^{7}$ is not too typical of A. paviei in its gonopodal conformation, the apicalmost branch being more slender and longer, thus being more strongly reminiscent of $A$. miranda (Pocock, 1895) or A. uncinata (Attems, 1931) as illustrated by Likhitrakarn et al. [2016a] and Nguyen et al. [2018]. How- 

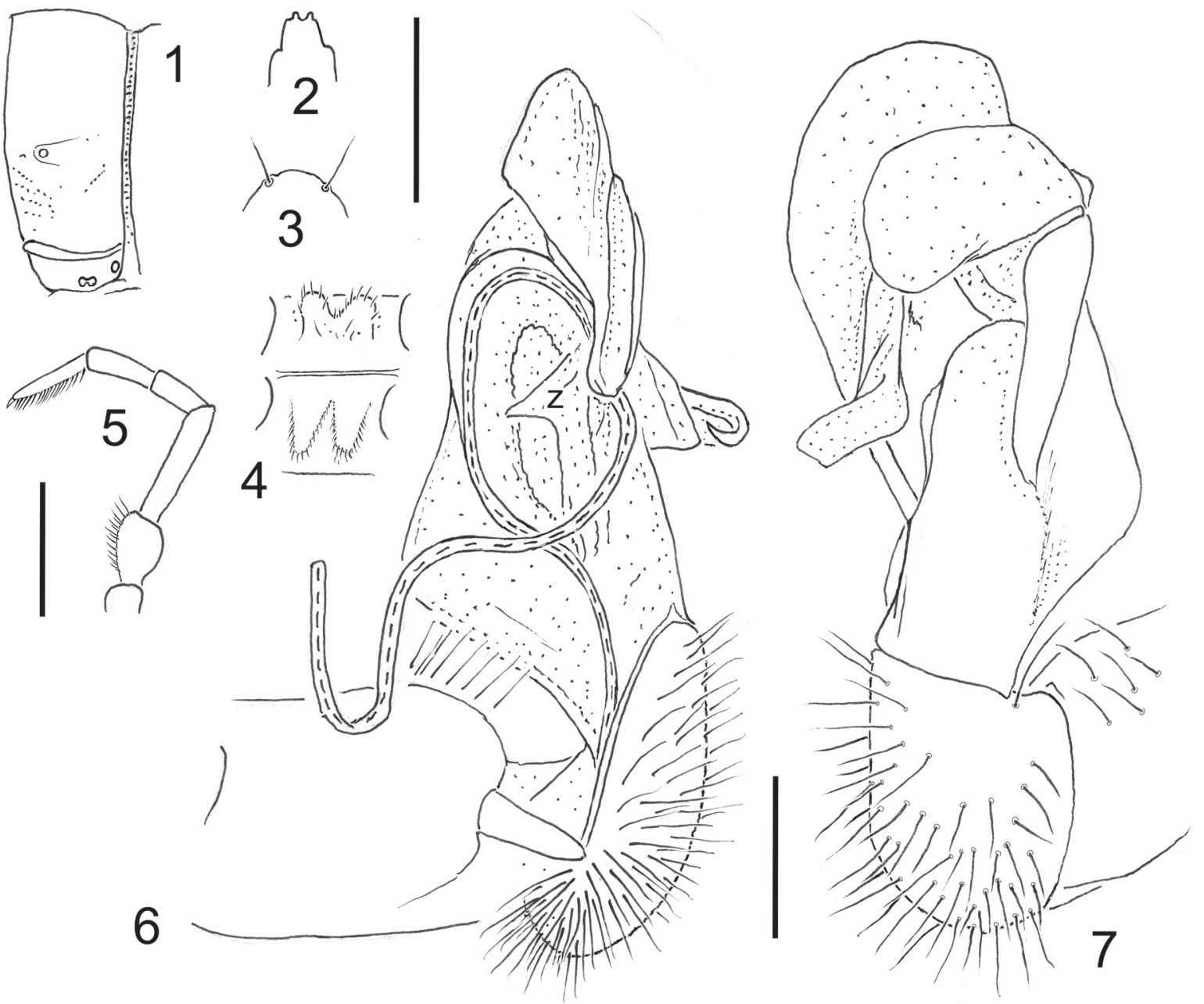

Figs 1-7. Anoplodesmus spiniger Chen, Golovatch, Mikhaljova et Chang, 2010, $0^{7}$ from Sheding Nature Park. 1 - segment 9, lateral view; 2 - epiproct, dorsal view; 3 - hypoproct, ventral view; 4 - sterna between coxae 4 (above) and 5 (below), ventral view; 5 - leg 7, lateral view; 6-7 - left gonopod, mesal and lateral views, respectively. Abbreviation: $\mathbf{z}$ - tooth on solenophore. Scale bars: $0.5 \mathrm{~mm}(1-$ 5) and $0.2 \mathrm{~mm}(6-7)$.

Pис. 1-7. Anoplodesmus spiniger Chen, Golovatch, Mikhaljova et Chang, 2010, О7 из Sheding Nature Park. 1 - сегмент 9, сбоку; 2 эпипрокт, сверху; 3 - гипопрокт, снизу; 4 - стерниты между тазиками 4 (выше) и 5 (ниже), снизу; 5 - нога 7, сбоку; 6-7 левый гонопод, соответственно изнутри и сбоку. Сокращение: $\mathbf{z}$ - зуб на соленофоре. Масштаб: 0,5 мм (1-5) и 0,2 мм (6-7).

ever, in all other respects it keys out to A. paviei [Likhitrakarn et al., 2016a].

\section{Desmoxytes planata (Pocock, 1895) Figs 8-14.}

MATERIAL. $1 \sigma^{7}$ (SMF), China, Yunnan Prov., Xishuangbanna, Menglun, Tropical Botanical Garden, N 21 $1^{\circ} 55^{\prime} 46.05$ ”, E $101^{\circ} 18^{\prime} 11.03$ ", $560 \mathrm{~m}$ a.s.l., secondary forest, on vegetation and by hand at night, 3. \& 5.X.2017, leg. P. Jäger; 1 \& (SMF), Thailand, Prachuap Khiri Khan Prov., Khao Sam Roi Yot National Park, stony path from Ban Bang Pu Beach to Laem Sala Beach, stones at viewpoint, 21.VII.2006, leg G. Hantke \& F. Brand.

REDESCRIPTION. Male ca $22 \mathrm{~mm}$ long, 1.1 and 2.1 mm wide on midbody pro- and metazonae, respectively. Female (identity to be verified) ca $23 \mathrm{~mm}$ long, 2.3 and 3.2 $\mathrm{mm}$ wide on midbody pro- and metazonae, respectively. General coloration of male in alcohol dark brown to blackish with a distinct pattern of whitish to light yellowish or light brownish paraterga, metatergal tubercles, venter and legs; tip of antenna also contrasting pallid against a blackish remaining antenna. Mid-dorsal regions of both pro- and metaterga slightly lighter, grey-brown. Female lighter brown, but pattern same as in male. No traces of a pink pigment characteristic of live specimens.

Head mostly microgranulate, densely setose and hirsute, only a little less so in vertigial region. Epicranial suture superficial. Antennae extremely long and slender, in situ reaching back to segment 5 when stretched dorsally. In length, antennomere $3=4=5>2=6>1>7$. Interantennal isthmus ca 0.8 times as broad as diameter of antennal socket. In width, head $<<$ collum $<$ segment $2=3<4<5-16\left(\bigcirc^{7}\right)$; thereafter body gradually tapering towards telson. Tegument clearly granulate throghout, prozonae mostly finely shagreened. Collum with three transverse rows of small setigerous knobs, regularly rounded laterally, with one lateral incision on each paratergum, the latter wing-shaped, well 


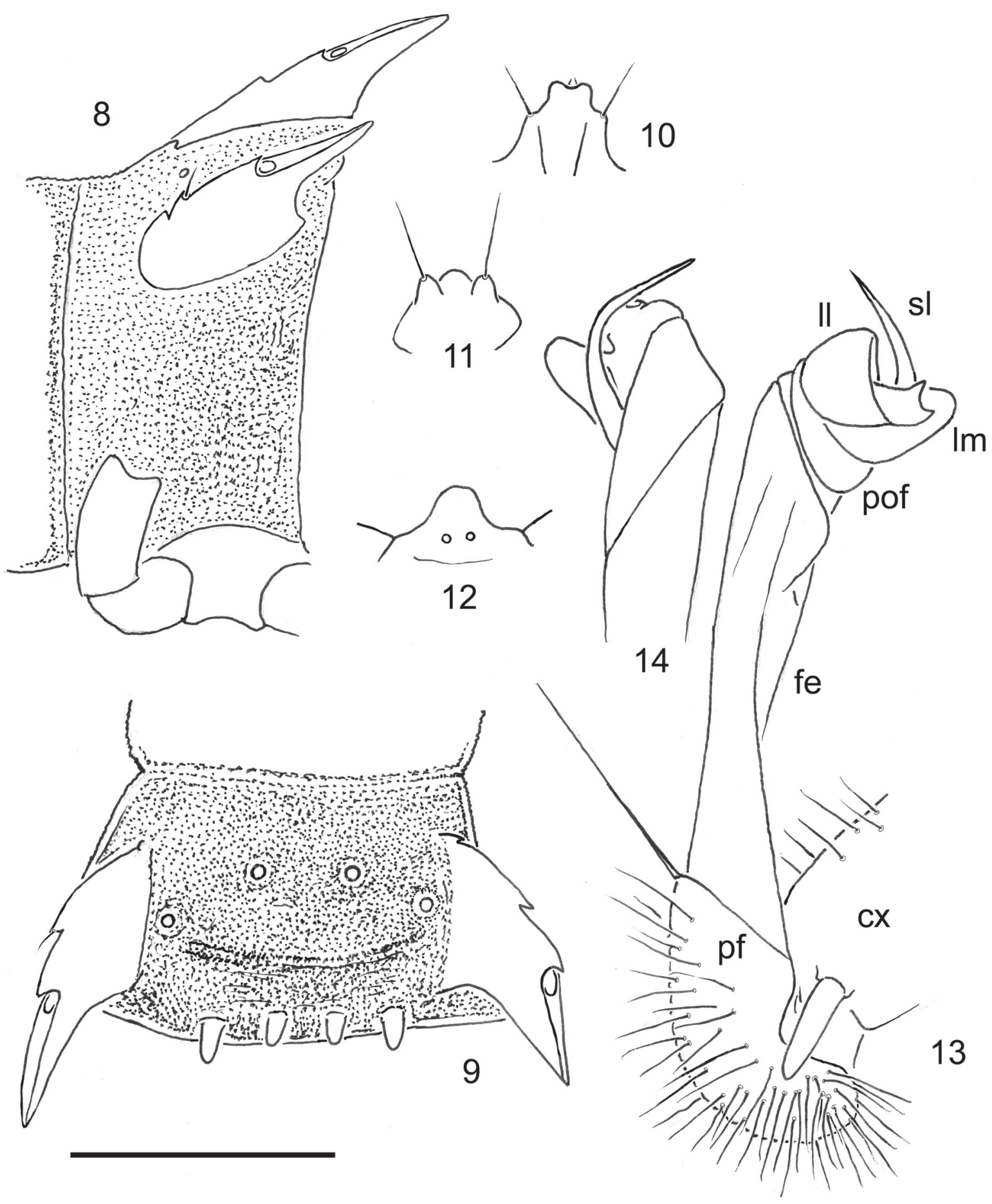

Figs 8-14. Desmoxytes planata (Pocock, 1895), O from Menglun. 8-9 - segment 9, lateral and dorsal views, respectively; $10-$ epiproct, dorsal view; 11 - hypoproct, ventral view; 12 - sternal lobe between coxae 4, ventral view; 13-14 — right gonopod, mesal and lateral views, respectively. Abbreviations: cx - coxite; pf - "prefemoral" part; fe - femorite; pof - postfemoral part; II - lamina lateralis; $\mathbf{I m}$ - lamina medialis. Scale bars: $1.0 \mathrm{~mm}(8-12)$ and $0.3 \mathrm{~mm}(13-14)$.

Рис. 8-14. Anoplodesmus spiniger Chen, Golovatch, Mikhaljova et Chang, 2010, О7 из Sheding Nature Park. 8-9 - сегмент 9, соответственно сбоку и сверху; 10 - эпипрокт, сверху; 11 - гипопрокт, снизу; 12 - стернальная пластинка между тазиками 4 , снизу; 13-14 - правый гонопод, соответственно изнутри и сбоку. Сокращения: $\mathbf{c x}$ - коксит; pf - "предбедренная" часть; $\mathbf{f e}-$ феморит; pof - постфеморальная часть; II - lamina lateralis; Im - lamina medialis. Масштаб: 1,0 мм (8-12) и 0,3 мм (13-14). 
elevated much like following ones, largely directed dorsocaudad and subacuminate at apex; only paraterga 17-19 directed strictly caudad. Dorsum between paraterga flattened, each metatergum with two transverse rows of $2+2$ tubercles, these being very small and poorly-visible in anterior row and considerable rounded cones in posterior row, both lateralmost being larger than both paramedian ones (Figs 8-9). Poriferous paraterga each with a particularly prominent distalmost incision to support a well-developed ozopore and a groove distal to it. Transverse metatergal sulci evident, arcuate, nearly reaching the bases of paraterga, present on metaterga 4-18. Stricture dividing pro- and metazonae thin and deep. Axial line missing. Pleurosternal carina a small ventral ridge on segment 2 , a still smaller ridge on segment 3, thereafter wanting $\left(O^{7}\right)$. Epiproct (Fig. 10) long, clearly flattened dorsoventrally, conical, very poorly emarginate at apex, subapical lateral papillae evident. Hypoproct (Fig. 11) subcircular, with a rounded apex, caudal 1+1 setae well-separated, borne on evident knobs.

Sterna densely setose, cross-impressions evident only due to transverse sulci, without modifications other than a small, roundly triangular, bare lobe between $\sigma^{7}$ coxae 4 , this lobe showing a parabasal pair of pores (Fig. 12). Legs very long and slender, ca 2.3-2.5 times as long as midbody height, slightly infuscate (brownish) distally, with neither adenostyles nor ventral brushes; in length, femora $>$ tibiae $=$ tarsi $>$ postfemora $>$ prefemora $=$ coxae. Most pregonopodal legs, including pairs 5 and 6 , broken off.

Gonopods (Figs 13-14) simple, suberect. Coxite (cx) considerably less than half as long as telopodite, subcylindrical, setose distoventrally. "Prefemoral" (= densely setose) part (pf) short, set off from femorite (fe) by an oblique sulcus. Femorite relatively long and slender, ca 3 times as long as either prefemoral part (pf) or a condensed postfemoral part (pof), the latter demarcated from fe by a lateral and a mesal sulcus. Solenomere (sl) very short, but rather prominent, spiniform, well exposed beyond a lobe-shaped, simpler lamina lateralis (II) and a more complex, bifid lamina medialis (Im), both laminae being subequally stout and poorly-developed and both forming a solenophore to support sl.

REMARKS. This is the only widespread, pantropical species of Desmoxytes Chamberlin, 1923, a rather large genus recently redefined and keyed by Srisonchai et al. [2018a]. The characteristic pink colour must have fully faded after an extended conservation in alcohol, but the vivid pattern is retained as dark brown to blackish with contrasting whitish to light yellow paraterga, venter and legs. The paraterga are mostly high and wing-shaped, each with only two marginal teeth. The caudal tubercles/spines (Figs 8-9) located between the paraterga are somewhat unusual in being blunt and rounded instead of typically sharp. Certain minor details of solenophore structure are also slightly different from those as depicted by Srisonchai et al. [2018a]. The above redescription is meant to refine the variation range of this highly widespread and common species.

However, given the considerable variations revealed in this species by Srisonchai et al. [2018a], there can be little doubt that the above male sample represents $D$. planata, even though its leg-pairs 5 and 6 are broken off. The provenance from a botanical garden is certainly evidence of its introduction.

Geniculodesmus inexpectatus (Attems, 1944)

MATERIAL. $1 \sigma^{7}, 1$ q (SMF), Taiwan, Kenting, near Howard Beach Resort, N 21 ${ }^{\circ} 56^{\prime} 17.63^{\prime \prime}$, E $120^{\circ} 48^{\prime} 31.85^{\prime \prime}, 24 \mathrm{~m}$ a.s.1., sec- ondary forest, daytime, Winkler extraction, 24.VI.2013, leg. P. Jäger.

REMARK. This likely anthropochore introduction to Taiwan (from Japan?) has recently been nicely redescribed [Chen et al., 2008].

Helicorthomorpha luzoniensis (Peters, 1864)

MATERIAL. $1 \mathrm{O}^{\top}$ (SMF), Laos, Bolikhamsay Prov., Nam Kading National Protected Area, N 18²1'34.4”, E 10409'15.5', 220 $\mathrm{m}$ a.s.1. $-\mathrm{N} 18^{\circ} 21^{\prime} 19.2$, E $104^{\circ} 09^{\prime} 23.5$, $360 \mathrm{~m}$ a.s.1., primary forest, stream bed, rock boulders, gravel, by hand at daytime, 24.III.2011, leg. P. Jäger \& L. Nophasead; $10^{7}, 1$ ㅇ (SMF), Indonesia, Banda Sea, Maluku Islands, Palau Ambon, Waai, 7.VII.1959 (ex: Museum Buitenzorg, Java, 14.IX.1960).

REMARKS. This anthropochore species is widespread between New Guinea and the Philippines, on the one hand, and southern China, on the other hand [Golovatch, Semenyuk, 2018]. It has already been recorded from Laos, albeit from the Luang Prabang Province [Golovatch, 2016]. The present report from a primary forest is interesting in showing the species' profound ecological plasticity.

\section{Hylomus jeekeli (Golovatch et Enghoff, 1994) Figs 15-20.}

MATERIAL. $2 O^{7} O^{7}$ (SMF), $1 O^{7}$ (ZMUM). Laos, Bokeo Prov., Nam Khan National Biodiversity Conservation Area, Ban Na Luang, N 20²1'51.7”, E $100^{\circ} 41^{\prime} 34.9$ ', $500 \mathrm{~m}$ a.s.1., disturbed primary forest, leaf litter, daytime, sieving, 10.VI.2013, leg. P. Jäger.

REMARKS. This species was described and so far remained known only from northern Thailand [Golovatch, Enghoff, 1994], thus being new to the fauna of Laos. It has recently been transferred to Hylomus Cook et Loomis, 1924 [Srisonchai et al., 2018a], a decision followed here. The new samples agree in almost every detail (Figs 15-20) with the original description [Golovatch, Enghoff, 1994], only the adenostyle on $\sigma^{7}$ femur 5 is a little longer (Fig. 18), while the distal tooth $(\mathbf{z})$ on the solenophore can be vestigial (Fig. 20).

Tetracentrosternus hoffmani Golovatch, 2013

MATERIAL. $1 \sigma^{7}$ (SMF), China, Yunnan Prov., Gaoligong Shan Mts, 2900-3100 m, 7.VI.2011, leg. J. Martens.

REMARK. The above sample is a strict topotype of this species [Golovatch, 2013].

\section{Spinaxytes typica sp.n. Figs 21-28.}

HOLOTYPE $O^{7}$ (SMF), Thailand, Prachuap Khiri Khan Prov., Khao Sam Roi Yot National Park, stony path from Ban Bang Pu Beach to Laem Sala Beach, stones at viewpoint, 21.VII.2006, leg G. Hantke \& F. Brand.

PARATYPES: $4 \odot^{7} \sigma^{7}, 5$ 우 (SMF), $1 \odot^{\top}, 1$ (ZMUM), same locality, together with holotype.

NAME. To emphasize the typical facies of the new species that fails to alter the generic diagnosis.

DIAGNOSIS. Following the available key to all nine known species of the genus Spinaxytes Srisonchai, Enghoff et Panha, 2018, all confined to southern Thailand and the adjacent parts of Malaysia and Myanmar [Srisonchai et al., 2018b], S. typica sp.n. is distinguished by the lack of adenostyles, combined with the presence of $4+4$ setae in the anterior row on the collum, the erect postfemoral part of the gonopod, the apically curved lamina medialis etc.

DESCRIPTION. Length ca 20-23 $\left(\sigma^{7}\right)$ or $21-25 \mathrm{~mm}$ (+), $1.3-1.4$ and $2.0-2.2\left(\sigma^{7}\right)$ or $2.0-2.1 \mathrm{~mm}$ and $2.4-2.6$ 


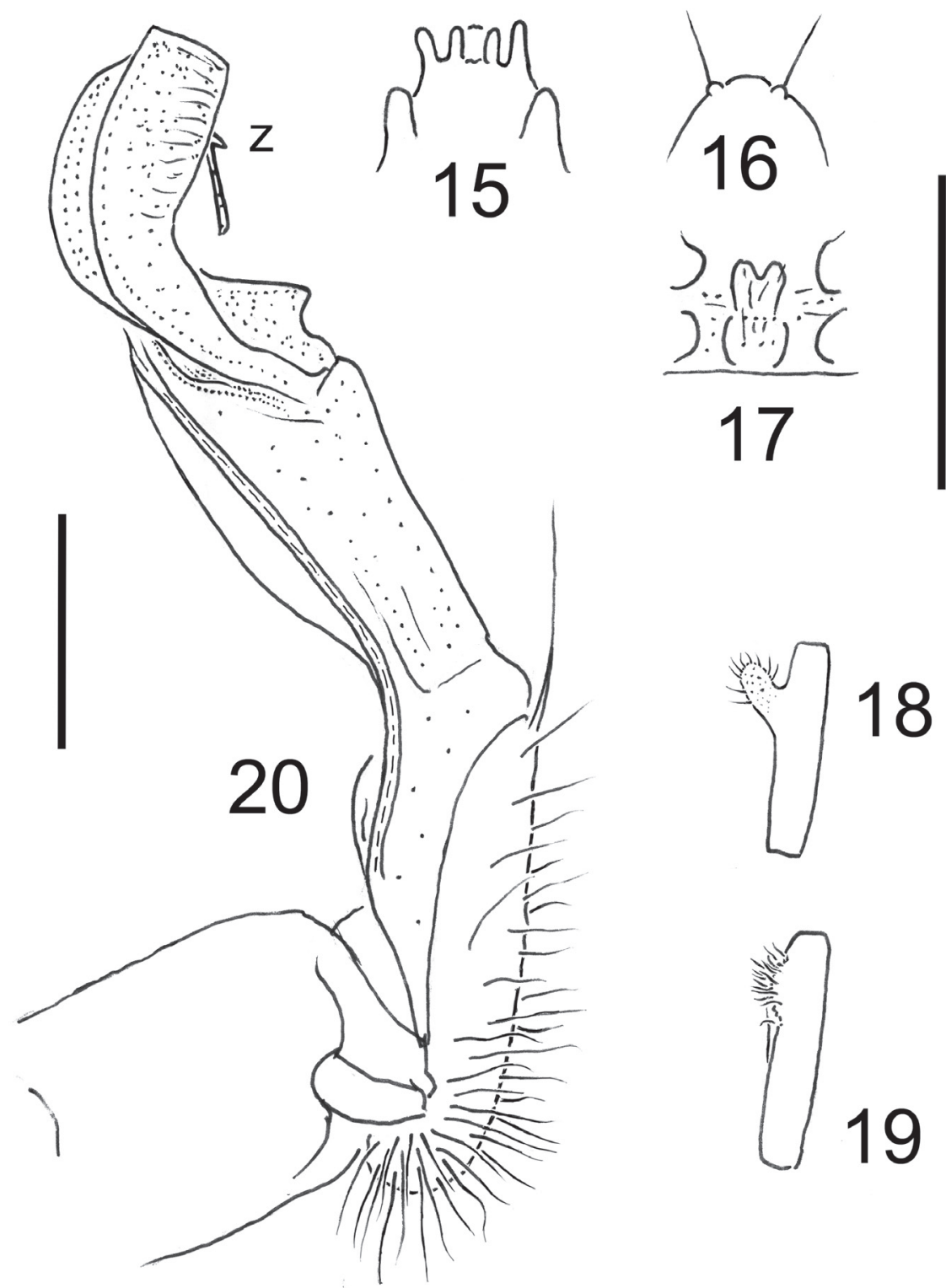

Figs 15-20. Hylomus jeekeli (Golovatch et Enghoff, 1994), O from Ban Na Luang. 15 - epiproct, dorsal view; 16 - hypoproct, ventral view; 17 - sternal lobe between coxae 4 and 5, ventral view; 18 - femur 6, lateral view; 19 - femur 7, lateral view; 20 - left gonopod, mesal view. Abbreviation: $\mathbf{z}$ - denticle in distal part of solenophore. Scale bars: $1.0 \mathrm{~mm}(15-19)$ and $0.2 \mathrm{~mm}(20)$.

Рис. 15-20. Hylomus jeekeli (Golovatch et Enghoff, 1994), О7 из Ban Na Luang. 15 - эпипрокт, сверху; 16 - гипопрокт, снизу; 17 - стернальная пластинка между тазиками 4 и 5 снизу; 18 - бедро 6, сбоку; 19 - бедро 7, сбоку; 20 - левый гонопод, изнутри. Сокращение: $\mathbf{z}$ - зубчик в дистальной части соленофора. Масштаб: 1,0 мм (15-19) и 0,2 мм (20).

$\mathrm{mm}(+)$ wide on midbody pro- and metazonae, respectively. Holotype ca $21 \mathrm{~mm}$ long, 1.3 and $2.0 \mathrm{~mm}$ wide on midbody pro- and metazonae, respectively. General coloration in alcohol uniformly brown to dark chocolate brown with a distinct pattern of light creamy to nearly pallid paraterga, metatergal tubercles, venter and basal podomeres; tip of antenna also contrasting pallid against a blackish antennomere 7 . Legs slightly, but increasingly infuscate, light brown distad.

Body moniliform. Head mostly microgranulate, very densely setose throughout, only a little less so in vertigial region. Epicranial suture superficial, a blackish impressed line. Antennae extremely long and slender, in situ reaching back to segment $6\left(O^{7}\right)$ or $5(+)$ when stretched dorsally. In length, antennomere $3>4>2=5>6>1=7$. Interantennal isthmus ca 0.9 times as broad as diameter of antennal socket. In width, head $<$ collum $<$ segment $2<3<4<5-16$; thereafter body gradually tapering towards telson. Tegument clearly granulate throughout, only prozonae mostly finely shagreened. Collum with three transverse rows of small setigerous knobs: $4+4$ in anterior row (including the lateralmost seta located at base of paratergum), $1+1$ in middle row and $2+2$ in posterior row (paramedian cones somewhat small- 

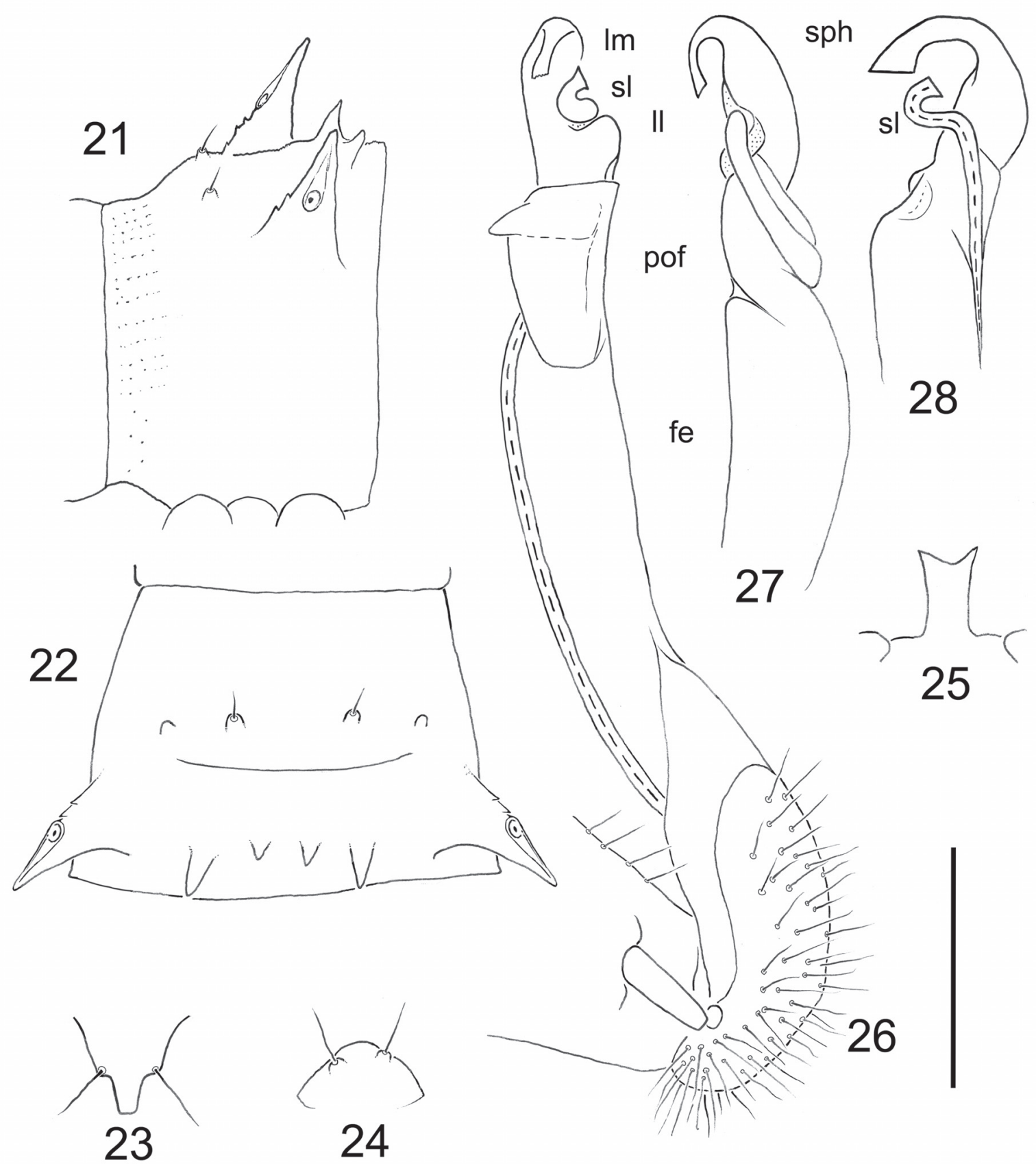

Figs 21-28. Spinaxytes typica sp.n., o paratype. 21-22 - segment 10, lateral and dorsal views, respectively; 23 - epiproct (tip turned down), dorsal view; 24 - hypoproct, ventral view; 25 - sternal lobe between coxae 4, ventrocaudal view; 26-28 - left gonopod, mesal, lateral and ventral views, respectively. Abbreviations: fe — femorite; pof — postfemoral part; sl - solenomere; sph — solenophore; Il - lamella lateralis; Im - lamella medialis. Scale bars: $1.0 \mathrm{~mm}(21-25)$ and $0.3 \mathrm{~mm}(26-28)$.

Рис. 21-28. Spinaxytes typica sp.n., паратип О'. 21-22 - сегмент 10, соответственно сбоку и сверху; 23 - эпипрокт (кончик вниз), сверху; 24 - гипопрокт, снизу; 25 - стернальная пластинка между тазиками 4, одновременно снизу и сзади; 26-28 левый гонопод, соответственно изнутри, сбоку и снизу. Сокращения: fe - феморит; pof - постфеморальная часть; sl соленомер; sph - соленофор; ll - lamella lateralis; Im - lamella medialis. Масштаб: 1,0 мм (21-25) и 0,3 мм (26-28).

er than larger lateral ones); paraterga spiniform, directed dorsocaudad, each with two denticles anteriorly and one lateral incision on each paratergum. Following meta- and paraterga much alike (Figs 21-22), with prominent, dorsocaudally directed, spine-shaped paraterga (somewhat longer in $\sigma^{7}$ compared to + ), with poriferous ones bearing an evident ozopore at base of $2^{\text {nd }}$ tooth, and $2+2$ small setigerous knobs in anterior row and $2+2$ larger, setigerous cones or spines in posterior row (Figs 21-22). Setae on collum and a few following anterior metaterga a little longer, being gradu- 
ally reduced and barely visible towards telson. Paraterga 18-19 directed caudad and reduced in size to lateral cones of posterior row. Transverse metatergal sulci inconspicuous, visible on metaterga 5-18, arcuate, not reaching the bases of paraterga. Stricture dividing pro- and metazonae very broad and shallow, granulate like adjacent metazona. Axial line missing. Pleurosternal carina a small ventral ridge on segments 2-3, thereafter wanting. Epiproct (Fig. 23) unusually slender, subtruncate, subapical lateral papillae very evident. Hypoproct (Fig. 24) semi-circular, with a rounded apex, caudal $1+1$ setae well-separated, borne on small knobs.

Sterna densely setose, cross-impressions evident only due to transverse sulci, without modifications other than a prominent, slender, flattened, bifid lobe between $\sigma^{7}$ coxae 4 (Fig. 25). Legs extremely long and slender, ca $4\left(\sigma^{7}\right)$ or $>2$ times $\left(\begin{array}{l}(+) \\ )\end{array}\right)$ as long as midbody height, with neither adenostyles nor ventral brushes; in length, femora $>$ tibiae $>$ tarsi $>$ postfemora $>$ prefemora $=$ coxae; claw very small, slightly curved ventrad. Legs 1 clearly stouter and shorter than following ones.

Gonopods (Figs 26-28) simple, suberect. Coxite about as long as "prefemoral" (= densely setose) part, subcylindri$\mathrm{cal}$, setose distoventrally. Femorite (fe) long and slender, ca 2 times as long as acropodite, a suberect postfemoral part (pof) set off from fe by a cingulum. Solenomere (sl) very short, but prominent, curved and twisted, with a flattened and truncate tip, well exposed beyond a small and simple lamina lateralis (II) and a more complex, larger, unciform lamina medialis (Im), both laminae forming a solenophore (sph) to support sl.

\section{Tylopus longisetosus sp.n. Figs 29-36.}

HOLOTYPE $\sigma^{7}$ (SMF), Laos, Bokeo Prov., Nam Khan National Biodiversity Conservation Area, Ban Na Luang, N 20²1'51.7”, E $100^{\circ} 41^{\prime} 34.9^{\prime \prime}, 500 \mathrm{~m}$ a.s.1., disturbed primary forest, leaf litter, daytime sieving, 10.VI.2013, leg. P. Jäger.

PARATYPE: $1 O^{7}$ (SMF), same data, together with holotype.

NAME. To emphasize the unusually long tergal setae.

DIAGNOSIS. Based on the latest available review and key [Likhitrakarn et al., 2016b], as well as considering further four species described since [Golovatch et al., 2016; Golovatch, Semenyuk, 2018], the large Oriental genus Tylopus Jeekel, 1968 is currently known to encompass 67 species from Indochina and the adjacent parts of southern China and Myanmar. Most of the species (31, or $>50 \%$ ) come from Thailand, followed by Vietnam (18), Laos (7), southern China (6) and Myanmar (4). Country endemism is close to $100 \%$, as only $T$. doriae (Pocock, 1895) and T. nodulipes (Attems, 1953) have been recorded from two of the countries at once (Myanmar and Thailand, and Vietnam and Laos, respectively). Hardly surprisingly, a few more new Tylopus spp. have been encountered, mostly in Laos and all described below.

This new species differs from congeners by the conspicuously moniliform body, coupled with poorly developed paraterga, the characteristic colour pattern which includes the light insertion spots of the unusually long, stiff and rather abundant tergal setae, and some minor details of the gonopodal structure, in particular, the lack of a medial gutter/excavation on the gonopodal femorite and the unequally bifid and prominent process $\mathbf{h}$ of the solenophore.

DESCRIPTION. Both holo- and paratype ca $11 \mathrm{~mm}$ long, width of midbody pro- and metazonae 0.5 and $0.7 \mathrm{~mm}$, respectively. General coloration in alcohol dark chocolate brown with a characteristic pattern of contrasting light, yellowish to nearly pallid paraterga, labrum, tips of antennae, tip of epiproct, strictures between pro- and metazonae, and insertion disks of tergal setae; venter and basal podomeres light grey-creamy, legs being slightly and increasingly infuscate grey brownish distad; vertex, genae and collum darker, blackish brown.

Clypeolabral region densely setose, vertigial one with a few setae only; epicranial suture thin, but evident. Antennae short and clearly clavate, in situ slightly extending only behind collum when stretched dorsally $\left(\sigma^{7}\right)$; antennomere 2 $=6>3=4>5>1=7$; interantennal isthmus about as broad as diameter of antennal socket.

Body strongly moniliform due to distict strictures and small, rounded paraterga. Tegument mostly smooth and shining, prozonae microreticulate/microalveolate, sides below paraterga very finely microgranulate; metaterga in places very delicately rugulose. In width, head $>>$ collum $=$ segment $2=5-16>$ segment $3=4$; body gradually and only moderately tapering towards telson on segments 17-20. Collum broadly and regularly rounded laterally. Postcollum paraterga poorly developed, but evident, mostly set at about half of body height, thicker on pore-bearing segments compared to poreless ones, smooth and regularly rounded laterally, each callus completely set off by a sulcus dorsally and another sulcus ventrally, lateral edge with 2-3 long setae, these mostly being abraded, but traceable due to small insertion points; caudolateral corner a small, subrectangular, often slightly rounded denticle never drawn caudally behind rear tergal margin; ozopores lateral, barely visible from above, lying inside an ovoid groove near caudolateral corner (Fig. 29). Transverse metatergal sulci evident, microgranulate at bottom, reaching the bases of paraterga, present on segments $5-18$, absent from $19^{\text {th }}$. Tergal setae often abraded, especially so on midbody metazonae, unusually long (about half or more as long as metatergum), stiff and, unlike setae on calluses, easily distinguished though small, light, round disks: collum with of $4+4,1+1$ and $2+2$ in three transverse rows; meteterga 2-4 or even 2-7 with only two transverse rows of setae $(2+2$ and $3+3)$; metatergum 8 with $2+2$ and $3+4$ setae; segments 9 and 10 each (Fig. 29) with $3+3,2+2$ and (4) $3+3$ setae in three rows. Both latter rows located behind transverse metatergal sulcus. Thereafter setation pattern gradually culminating in $5+5,5+5$ and $5+5$ arranged in three, often rather irregular, transverse rows on metatergum 19. Stricture dividing pro- and metazonae thin and deep, clearly ribbed at bottom down to below paraterga. Pleurosternal carinae low, arcuated lobes or ridges present only on segments 2-4, thereafter missing. Limbus microcrenulate. Axial line present only in rear halves of metaterga (Fig. 29). Epiproct conical, subtruncate at apex, subapical lateral papillae very small (Fig. 30). Hypoproct (Fig. 31) semi-circular, caudal 1+1 setae well-separated, not borne on knobs.

Sterna sparsely setose, without modifications except for a roundly subtriangular setose lobe (Fig. 32) between coxae $4\left(\mathrm{O}^{7}\right)$; cross-impressions moderate. Adenostyles missing. Legs rather short and stout, 1.2-1.3 times as long as midbody height $\left(\mathrm{O}^{7}\right)$; in length, femora $>$ tarsi $>$ prefemora $>$ coxae $=$ tibiae $=$ postfemora; claw simple, slightly curved ventrad; prefemora not inflated laterally (Fig. 33). Tarsal brushes distinct, present on all legs $\left(\sigma^{7}\right)$ except two last pairs (Fig. 33).

Gonopods (Figs 34-36) relatively short, stout and simple, in situ held parallel to each other; coxite much shorter 

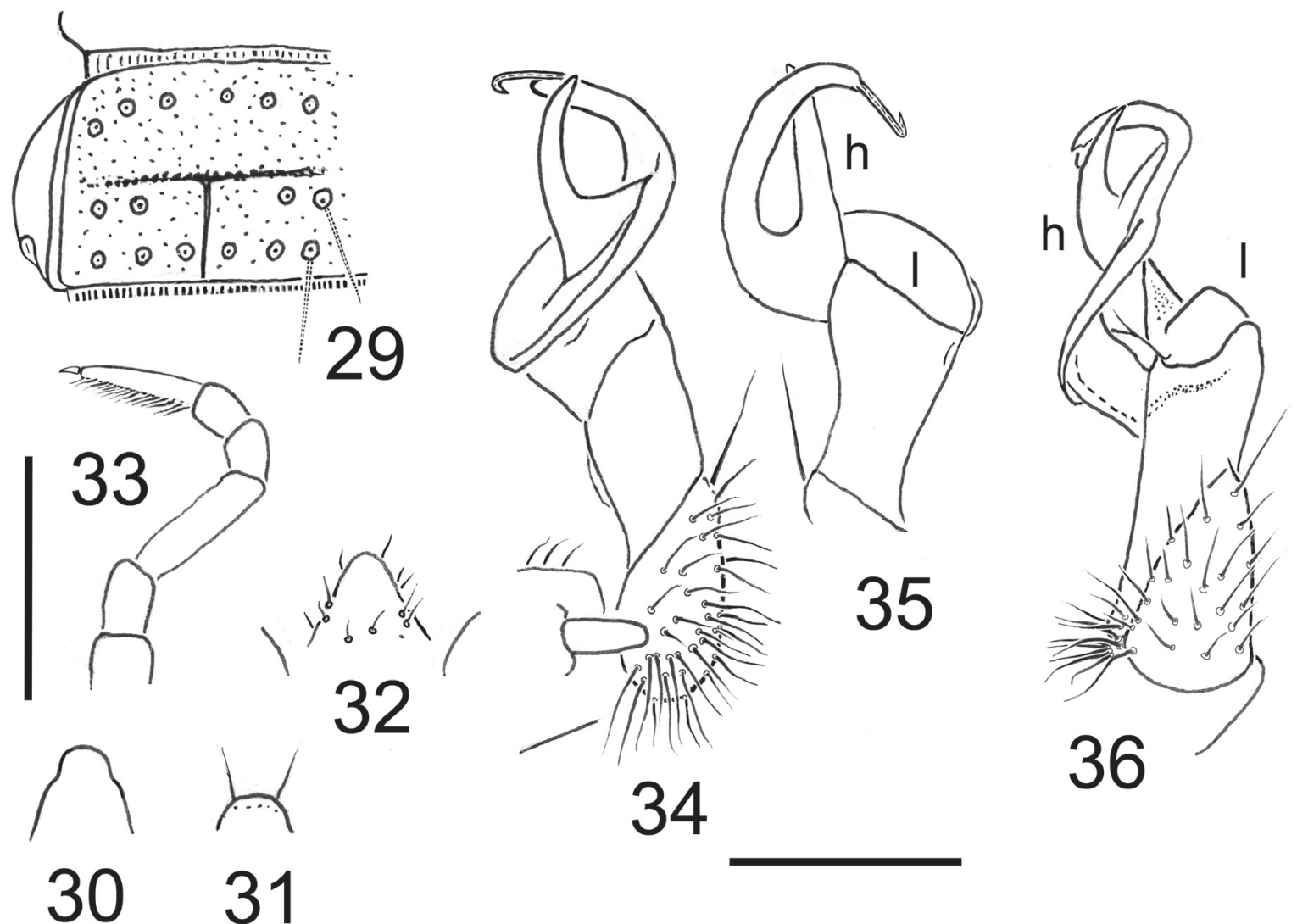

Figs 29-36. Tylopus longisetosus sp.n., $0^{7}$ paratype. 29 - left half of segment 9, dorsal view; 30 - epiproct, dorsal view; 31 hypoproct, ventral view; 32 - sternal lobe between coxae 4, ventrocaudal view; 33 - leg 9, lateral view; 34-36 — left gonopod, mesal, lateral and ventral views, respectively. Abbreviations: $\mathbf{I}$ - postfemoral lateral lobe; $\mathbf{s} \mathbf{l}$ - solenomere; $\mathbf{h}$ - basal process of solenophore. Scale bars: $0.5 \mathrm{~mm}(29-33)$ and $0.5 \mathrm{~mm}(34-36)$.

Рис. 29-36. Tylopus longisetosus sp.n., паратип О'. 29 - левая половина сегмента 9, сверху; 30 - эпипрокт, сверху; 31 гипопрокт, снизу; 32 - стернальная пластинка между тазиками 4, одновременно снизу и сзади; 33 - нога 9, сбоку; $34-36$ левый гонопод, соответственно изнутри, сбоку и снизу. Сокращения: $\mathbf{l}$ - постфеморальная боковая пластинка; sl - соленомер; $\mathbf{h}-$ базальный отросток соленофора. Масштаб: 0,5 мм (29-33) и 0,5 мм (34-36).

than telopodite, slender, subcylindrical, with several long setae distoventrally; telopodite short, "prefemoral" (= densely setose) part about as long as a distad slightly enlarged femorite, the latter devoid of a mesal gutter/excavation and set off from a postfemoral part by a distinct cingulum demarcating, on lateral side, a rounded apical lobe (I). A long, coiled, slender solenophore (sph) twisted around an unequally bifid and prominent process $\mathbf{h}$; tip of solenomere (sl) visibly exposed beyond sph.

\section{Tylopus hirsutus sp.n. Figs 37-45.}

HOLOTYPE $\sigma^{7}$ (SMF), Laos, Luang Prabang Prov., Phou Khoun Distr., N 19²6’4.3”, E 102²9’16.6”, Tham Deu, 5.I.2007, leg. H. Steiner.

NAME. To emphasize the densely hairy/hirsute collum and following metaterga.

DIAGNOSIS. Following the latest review and key [Likhitrakarn et al., 2016b], also considering further four species described since [Golovatch et al., 2016; Golovatch, Semenyuk, 2018], as well as another few species described above and below, T. hirsutus sp.n. differs primarily by the very densely, irregularly and sometimes confusedly hirsute collum and following metaterga, coupled with well-developed paraterga, a deeply emarginate epiproct tip, a bipartite lobe between $\sigma^{7}$ coxae 4 , a short and stout process $h$ at the base of a long, slender, coiled solenophore etc.

DESCRIPTION. Holotype ca $18 \mathrm{~mm}$ long, width of midbody pro- and metazonae 1.7 and $2.1 \mathrm{~mm}$, respectively. General coloration in alcohol marbled brown with a characteristic cingulated pattern of contrasting light, yellowish, grey to nearly pallid paraterga, strictures between pro- and metazonae, venter and basal podomeres; anterior $1 / 4-1 / 5$ of each postcollum metatergum infuscate, marbled dark brown as opposed to lighter brown to yellow-brown remaining parts of metaterga; legs light reddish brown, slightly and increasingly infuscate brownish distad; antennae light yellow, but distal half of antennomere 6 and entire $7^{\text {th }}$ increasingly infuscate, dark brown to blackish; tergal hairs, their insertion disks and tegument transparent.

Clypeolabral region densely setose, vertigial one bare; epicranial suture superficial. Antennae short and clearly clavate, in situ slightly extending only behind segment 2 when 


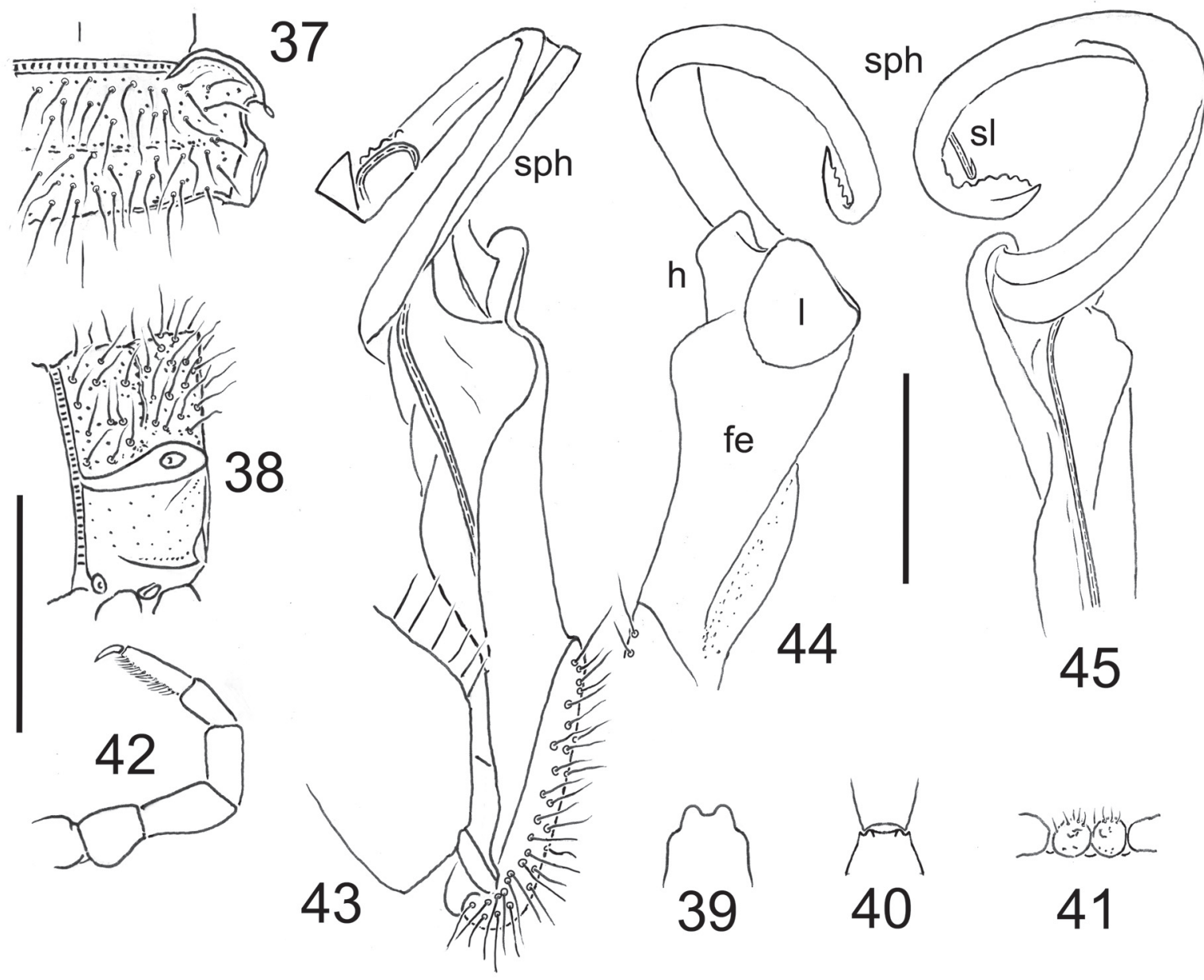

Figs 37-45. Tylopus hirsutus sp.n., $\mathrm{O}^{7}$ holotype. 37-38 - right half of and nearly entire segment 9, dorsal and lateral views, respectively; 39 - epiproct, dorsal view; 40 - hypoproct, ventral view; 41 - sternal tubercles between coxae 4, ventral view; 42 - leg 5, lateral view; 43-45 - left gonopod, mesal, lateral and ventral views, respectively. Abbreviations: fe - femorite; I - postfemoral lateral lobe; $\mathbf{s p h}$ - solenophore; sl - solenomere; $\mathbf{h}$ - basal process of solenophore. Scale bars: $1.0 \mathrm{~mm}(37-42)$ and $0.5 \mathrm{~mm}(43-45)$.

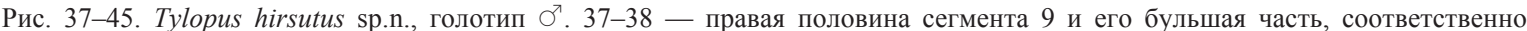
сверху и сбоку; 39 - эпипрокт, сверху; 40 - гипопрокт, снизу; 41 - стернальные бугорки между тазиками 4, снизу. Сокращения: fe - феморит; $\mathbf{l}$ - постфеморальная боковая пластинка; $\mathbf{s p h}$ - соленофор; $\mathbf{s l}$ - соленомер; $\mathbf{h}$ - базальный отросток соленофора. Масштаб: 1,0 мм (37-42) и 0,5 мм (43-45).

stretched dorsally $\left(\sigma^{7}\right)$; antennomere $2=3=4=5=6>>1$ $=7$; interantennal isthmus ca 0.8 times as broad as diameter of antennal socket.

Tegument mostly dull and microgranulate, only prozonae shining and microreticulate/microalveolate, sides below paraterga very finely microgranulate; metaterga in places rugulose. In width, head $<$ collum $=$ segment $3=4<2<5$ 16; thereafter body gradually tapering towards telson. Collum broadly and regularly rounded laterally, with one lateral setigerous incision near midlength, caudal corner broadly and regularly rounded. Postcollum paraterga rather well developed, mostly set at about half of body height, thicker on pore-bearing segments compared to poreless ones. Paraterga 2 drawn both anteriad and posteriad, caudal corner acute (nearly a regular triangle), like all following poreless paraterga with two lateral setigerous incisions/teeth on a narrow callus. Pore-bearing paraterga with one evident setigerous incision/tooth in anterior $1 / 3$ of a thicker callus, followed by a sinuate posterior 1/3 marking ozopore position (Fig. 37).
Each callus completely set off by a sulcus dorsally, but a complete ventral sulcus present only on pore-bearing segments. Caudolateral corner acute and acuminate (Figs 3738 ), but clearly drawn behind rear tergal margin only in segments 15-19. Ozopores lateral, barely visible from above, lying inside an ellipsoid groove at $1 / 3$ off caudolateral corner (Figs 37-38). Collum and following metaterga beset with thin, abundant, irregular, silky, sometimes confused hairs, these typically being $>1 / 2$ as long as metatergum and each borne on a very small, round, transparent disk. Transverse metatergal sulci evident, granulate at bottom, almost reaching the bases of paraterga, present on segments 5-18, absent from $19^{\text {th }}$. Stricture dividing pro- and metazonae thin and deep, clearly ribbed at bottom down to below paraterga. Pleurosternal carinae evident arcuated ridges with an increasingly well developed, sharp, caudal tooth up to segment 7 , thereafter gradually reduced and forming only a small rectangular flap on segments 17 and 18. Axial line present only on metaterga and only in places, traceable as a 
thin lighter line against a darker background. Epiproct conical, deeply emarginate at apex, subapical lateral papillae small, but evident (Fig. 39). Hypoproct (Fig. 40) subtrapeziform, caudal 1+1 setae well-separated, borne on small knobs.

Sterna densely setose, without modifications except for a paramedian pair of small, contiguous, round, setose tubercles (Fig. 32) located between coxae $4\left(O^{7}\right)$; cross-impressions moderate. Adenostyles missing. Legs medium-sized, stout (Fig. 42), apparently crassate compared to + , ca $1.5-$ 1.6 times as long as midbody height $\left(O^{7}\right)$; in length, femora $>$ tarsi $=$ postfemora $>$ coxae $=$ prefemora $=$ tibiae; claw sim ple, slightly curved ventrad; prefemora inflated laterally $\left(O^{7}\right)$. Tarsal brushes distinct, present on all legs $\left(O^{7}\right)$ except two last pairs (Fig. 42).

Gonopods (Figs 43-45) relatively complex; coxite much shorter than telopodite, subcylindrical, setose distoventrally; "prefemoral" (= densely setose) part of telopodite about as long as a distad slightly enlarged femorite (fe), the latter with a distinct mesal gutter/excavation and set off from a postfemoral part by a distinct cingulum demarcating, on lateral side, a rounded apical lobe (I). A long, coiled, slender solenophore (sph) twisted around a short, squarish, lobeshaped, basal process $\mathbf{h}$; tip of solenomere (sl) barely exposed beyond sph.

REMARK. The type locality being a cave (= Tham) is certainly random, because this species shows no signs of troglomorphism whatsoever.

\section{Tylopus subtuberculatus sp.n. Figs 46-54.}

HOLOTYPE $\sigma^{7}$ (SMF), Laos, Champasak Prov., Muang

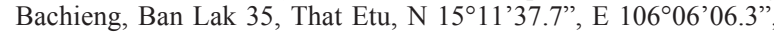
$810 \mathrm{~m}$ a.s.l., secondary forest, vegetation, under stones, stairway to waterfall, at night, by hand, 22.XI.2012, leg. P. Jäger.

NAME. To emphasize the similarity to T. tuberculatus Golovatch et Semenyuk, 2018, from southern Vietnam [Golovatch, Semenyuk, 2018].

DIAGNOSIS. Based on the metatergal tuberculation and its pattern, the well-developed paraterga, the absence of adenostyles, the general gonopodal configuration etc., this new species seems to be particularly similar to T. tuberculatus Golovatch et Semenyuk, 2018. However, T. subtuberculatus sp.n. differs clearly by the larger size (31 vs. 24-25 $\mathrm{mm}$ long), the less strongly sharpened caudal corners of paraterga (Figs 47-48), the absence of tergal tubercles from the collum, the relatively short antennae and small interantennal isthmus etc.

DESCRIPTION. Holotype ca $31 \mathrm{~mm}$ long, width of midbody pro- and metazonae 2.3 and $3.0 \mathrm{~mm}$, respectively. General coloration in alcohol blackish brown with a characteristic pattern of contrasting light yellowish to brownish paraterga, pleurosternal carinae, venter and some of setigerous tergal tubercles; legs light brown, slightly and increasingly infuscate distad; antennae brown, increasingly blackish towards antennomeres 6 and, especially, 7; tergal setae light.

Clypeolabral region densely setose, vertigial one nearly bare; epicranial suture superficial. Antennae rather short and clavate, in situ slightly extending behind only to segment 3 when stretched dorsally $\left(O^{7}\right)$; antennomere $2=3=4=5=6$ $>>1>7$; interantennal isthmus ca 0.7 times as broad as diameter of antennal socket.

Tegument mostly dull, microgranulate, coriaceous and striolate, only prozonae shining and microreticulate/microal- veolate, sides below paraterga microgranulate. In width, head $<$ collum $<$ segment $2<3=4<5-16$; thereafter body gradually tapering towards telson. Collum broadly and regularly rounded laterally, with one lateral setigerous incision near midlength, caudal corner broadly and regularly rounded. Postcollum paraterga rather well developed, mostly set at about $1 / 3-1 / 4$ of body height, thicker on pore-bearing segments compared to poreless ones, subhorizontal to slightly upturned. Paraterga 2 drawn both anteriad and posteriad, caudal corner acute (at about $70^{\circ}$ ), unlike all following paraterga with 4-5 insertion points of setae at each lateral margin, thereafter with 1-2 lateral setigerous insertions on a narrow callus. Pore-bearing paraterga with one evident setigerous incision/tooth in anterior $1 / 3$ of a thicker callus, followed by a sinuate posterior $1 / 3$ marking ozopore position (Fig. 47). Each callus completely set off by a sulcus both dorsally and ventrally. Caudolateral corner acute and subacuminate, but never really pointed (Figs 46-47), increasingly clearly drawn behind rear tergal margin, but especially long and subspiniform only in segments 16-19. Ozopores lateral, barely visible from above, lying inside an ellipsoid groove at ca 1/3 off caudolateral corner (Figs 4647). Collum with three transverse rows of short simple setae: $4+4,1+1$ and $2+2$, all devoid of meaningful knobs/tubercles. Following metaterga with two transverse rows of similar setae, $2+2$ and $2+2$ in each row, but each seta ca $1 / 5$ as long as metatergum and located on an evident tubercle or knob. Anterior rows on segments 2 and 3 borne on particularly small and round knobs, thereafter gradually turning (nearly) as high and longitudinally oblong as posterior row. Tuberculation pattern generally $2+2$ and $2+2$ (Fig. 47), but posterior/postsulcus row $2+3$ in segment 11 and $3+3$ in segments 18 and 19 . Transverse metatergal sulci evident, finely granulate at bottom, reaching the bases of paraterga, fully present on segments $5-18$, slightly shortened on $4^{\text {th }}$, absent from $19^{\text {th }}$. Stricture dividing pro- and metazonae thin and deep, clearly ribbed at bottom down to below paraterga. Pleurosternal carinae evident arcuated ridges with an increasingly well developed, blunt, granulate, caudal tooth up to segment 7 , thereafter gradually reduced, abbreviated and caudally forming only a small subrectangular bulge to segment 11 (Fig. 46). Axial line present on both halves of metaterga, thin, but evident (Fig. 46). Limbus microcrenulate. Epiproct conical, clearly emarginate at apex, subapical lateral papillae small, but visible (Fig. 48). Hypoproct (Fig. 49) semicircular, caudal $1+1$ setae well-separated, borne on minute knobs.

Sterna very densely setose (Fig. 51), modifications being expressed as a small, but evident and sharp cone near each coxa (Fig. 51) and a high, roundly subtrapeziform, setose lobe (Fig. 50) between coxae $4\left(O^{7}\right)$; cross-impressions moderate, transverse impressions a little deeper than axial ones. Adenostyles missing. Legs rather long (Fig. 51), apparently crassate compared to 9 , ca 1.6-1.7 times as long as midbody height $\left(\sigma^{7}\right)$; in length, femora $=$ tarsi $>$ prefemo$\mathrm{ra}=$ tibiae $>$ postfemora $>$ coxae; claw simple, slightly curved ventrad; prefemora clearly inflated laterally $\left(O^{7}\right)$ until about caudal $1 / 3$ of body. All podomeres with ventral brushes to leg 9 (Fig. 51), thereafter gradually thinning out to caudal $1 / 3$ of body.

Gonopods (Figs 52-54) relatively complex; coxite much shorter than telopodite, subcylindrical, setose distoventrally; "prefemoral" (= densely setose) part of telopodite about as long as a distad slightly enlarged femorite (fe), the latter with a distinct mesal gutter/excavation and set off from a 


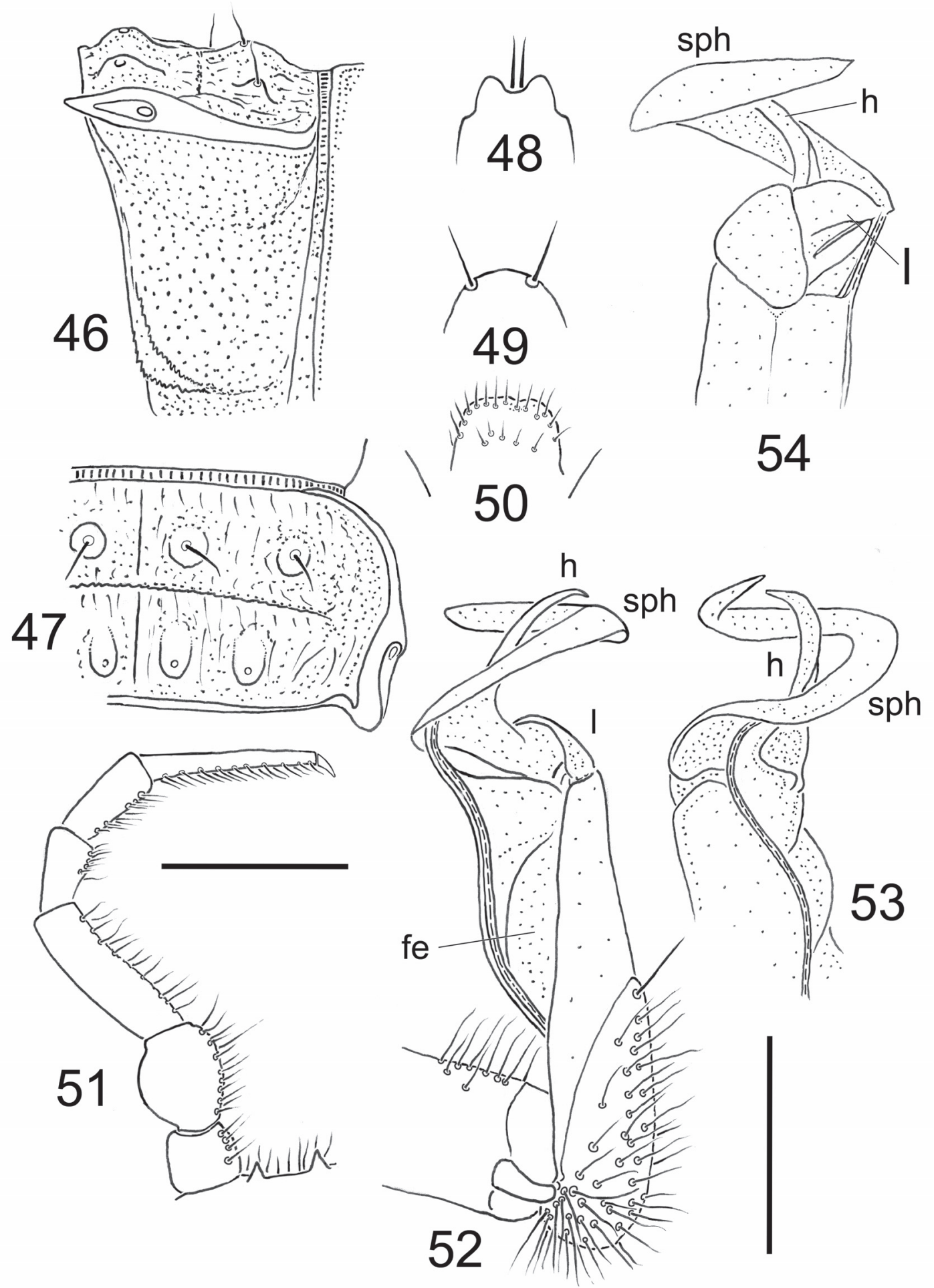

Figs 46-54. Tylopus subtuberculatus sp.n., O holotype. 46-47 - segment 9 and its right half, lateral and dorsal views, respectively; 48 - epiproct, dorsal view; 49 - hypoproct, ventral view; 50 - sternal lobe between coxae 4, ventral view; 51 - leg 9 with sternal cones, caudal view; 52-54 - left gonopod, mesal, ventral and lateral views, respectively. Abbreviations: fe - femorite and its gutter; $\mathbf{I}-$ postfemoral lateral lobe; sph - solenophore; $\mathbf{h}$ - basal process of solenophore. Scale bars: $1.0 \mathrm{~mm}(46-51)$ and $0.5 \mathrm{~mm}(52-54)$.

Рис. 46-54. Tylopus subtuberculatus sp.n., голотип O’. 46-47 - сегмент 9 и его правая половина, соответственно сбоку и сверху; 48 - эпипрокт, сверху; 49 - гипопрокт, снизу; 50 - стернальная пластинка между тазиками 4, снизу; 51 - нога 9 со стернальными шипиками, снизу; 52-54 - левый гонопод, соответственно изнутри, снизу и сбоку. Сокращения: fe - феморит и его выемка; $\mathbf{I}$ - постфеморальная боковая пластинка; $\mathbf{s p h}$ - соленофор; $\mathbf{h}$ - базальный отросток соленофора. Масштаб: 1,0 мм (46-51) и 0,5 мм (52-54). 
postfemoral part by a distinct cingulum demarcating, on lateral side, a rounded apical lobe (I). A long, coiled, slender, subacuminate solenophore (sph) twisted around a long, subspiniform, helicoid, acuminate, basal process $\mathbf{h}$; tip of solenomere not exposed beyond sph.

\section{Tylopus jaegeri sp.n.}

Figs 55-63.

HOLOTYPE $0^{7}$ (SMF), Laos, Luang Nam Tha Prov., Muang Sing, Nam Det, N $21^{\circ} 10.193^{\prime}$, E $101^{\circ} 14.445^{\prime}-$ N 2109.983', E $101^{\circ} 14.742^{\prime}, 820-1100 \mathrm{~m}$ a.s.l., secondary forest, along path, soil and vegetation, by hand, sieving, 6.XI.2004, leg. P. Jäger \& V. Vedel.

NAME. Honours Peter Jäger, the main collector and keeper of the Arachnida and Myriapoda Collection at the SMF.

DIAGNOSIS. Using the latest key to Tylopus species [Likhitrakarn et al., 2016b], also considering the species described since [Golovatch et al., 2016; Golovatch, Semenyuk, 2018] and herewith, T. jaegeri sp.n. keys out to couplet 20 , but fails to fit any particular species thereafter. It differs through a peculiar combination of characters such as no vivid colour pattern, well-developed paraterga and pleurosternal carinae, a coriaceous texture of the metaterga showing a setation pattern of $2+2$ and $2+2$ or, in a few posterior segments, $3+3$, strongly inflated $\sigma^{x}$ prefemora, a distinct spiniform process (r) on top of the gonopodal postfemoral lateral lobe $\mathbf{l}$, a parabasal spinicle $\mathbf{z}$ on the basal process $\mathbf{h}$ of the solenophore etc. Particularly close similarities seem to lie to the next new species below.

DESCRIPTION. Holotype ca $30 \mathrm{~mm}$ long, width of midbody pro- and metazonae 2.3 and $3.0 \mathrm{~mm}$, respectively. General coloration in alcohol brown with lighter, yellowish to geyish brown head, most of antennae (except for a dark brown antennomere 7), paraterga, dorsal parts of prozonae, pleurosternal regions, venter and, even more contrasting, legs light yellowish to brownish; tergal setae and tips of antennae pallid.

Clypeolabral region densely, vertigial one sparsely, setose; epicranial suture superficial. Antennae rather short and clavate, in situ slightly extending behind only to segment 3 when stretched dorsally $\left(O^{7}\right)$; antennomere $2=3=4=5=6$ $>>1>7$; interantennal isthmus ca 0.6 times as broad as diameter of antennal socket.

Tegument mostly dull, microgranulate, coriaceous and striate/striolate, only prozonae shining and microreticulate/ microalveolate, sides below paraterga microgranulate. In width, head $<$ collum $<$ segment $3=4<2<5-16$; thereafter body gradually tapering towards telson. Collum broadly and regularly rounded laterally, with one lateral setigerous incision near midlength, caudal corner broadly and regularly rounded. Postcollum paraterga rather well developed, mostly set at about $1 / 3$ of body height (Figs 55-56), thicker on pore-bearing segments compared to poreless ones, subhorizontal to slightly upturned. Paraterga 2 drawn both anteriad and posteriad, caudal corner acute (at about $65^{\circ}$ ), unlike all following paraterga with four insertion points of setae at each lateral margin, thereafter with 1-2 lateral setigerous insertions on a narrow callus. Pore-bearing paraterga with one evident setigerous incision in anterior $1 / 3$ of a thicker callus, followed by a sinuate posterior $1 / 3$ marking ozopore position (Fig. 56). Each callus completely set off by a sulcus both dorsally and ventrally. Caudolateral corner narrowly rounded to subacuminate, but never really pointed (Figs 55-
$56)$, increasingly clearly drawn behind rear tergal margin in segments $2-4$ and $12-19$, especially long and subspiniform only in segments 16-19. Ozopores lateral, barely visible from above, lying inside an ellipsoid groove at ca $1 / 3$ off caudolateral corner (Figs 55-56). Collum with three transverse rows of short simple setae: $4+4,1+1$ and $2+2$, all devoid of meaningful knobs/tubercles. Following metaterga with two transverse rows of similar, but mostly abraded setae, each seta ca $1 / 4$ as long as metatergum, setation pattern $2+2$ and $2+2$ or, in a few last segments, $3+3$ in each row, mostly traceable due to insertion points. Transverse metatergal sulci evident, slightly sinuate, finely granulate at bottom, almost reaching the bases of paraterga, present on segments $5-18$, absent from $19^{\text {th }}$. Stricture dividing pro- and metazonae thin and deep, clearly ribbed at bottom down to below paraterga. Pleurosternal carinae evident arcuated ridges with an increasingly well developed, sharp, caudal tooth up to segment 7, thereafter gradually reduced to segment 16 (Fig. 55). Axial line missing. Limbus microcrenulate. Epiproct conical, emarginate at apex, subapical lateral papillae evident (Fig. 57). Hypoproct (Fig. 58) semi-circular, caudal $1+1$ setae well-separated, borne on minute knobs.

Sterna very densely setose, with neither evident sternal cones nor other modifications except for a high, roundly subtrapeziform, setose lobe (Fig. 59) between coxae $4\left(O^{7}\right)$; cross-impressions moderate, transverse impressions a little deeper than axial ones. Adenostyles missing. Legs long (Fig. $60)$, apparently crassate compared to + , ca $1.6-1.7$ times as long as midbody height $\left(\sigma^{\top}\right)$; in length, femora $>$ tarsi $=$ prefemora $>$ postfemora $=$ tibiae $>$ coxae; claw simple, slightly curved ventrad; prefemora very strongly inflated laterally $\left(O^{7}\right)$. All podomeres with ventral brushes up to last two pairs (Fig. 60).

Gonopods (Figs 61-63) rather complex; coxite much shorter than telopodite, subcylindrical, setose distoventrally; "prefemoral" (= densely setose) part of telopodite almost as long as a distad slightly enlarged femorite (fe), the latter with a distinct mesal gutter/excavation and set off from a postfemoral part by a distinct cingulum demarcating, on lateral side, a subtriangular apical lobe (I) with a small spine (r) on top. A long, coiled, slender, subacuminate solenophore (sph) twisted around a long, subspiniform, helicoid, acuminate, basal process $\mathbf{h}$ with a lateral parabasal spinicle (z); tip of solenomere not exposed beyond sph.

\section{Tylopus altmannae sp.n.} Figs 64-72

HOLOTYPE $\sigma^{7}$ (SMF), Laos, Hoaphan Prov., Vieng Tong Distr., N 20¹3'23.6”, E 103²3'56.5”, Tham Thia Thong, 18.I.2007, leg. H. Steiner.

PARATYPE: 1 subadult + (SMF), same data, together with holotype.

NAME. Honours Julia Altmann, the keeper's assistant at the SMF.

DIAGNOSIS. Using the latest key to Tylopus species ]Likhitrakarn et al., 2016b], also considering the species described since [Golovatch et al., 2016; Golovatch, Semenyuk, 2018], T. altmannae sp.n. keys out to couplet 5, but fails to fit any particular species thereafter. In contrast, based on numerous characters, both peripheral and gonopodal, it seems to be especially similar to T. jaegeri sp.n., but differs in a number of details given in the description below.

DESCRIPTION. Holotype ca $31 \mathrm{~mm}$ long, width of midbody pro- and metazonae 2.4 and $3.1 \mathrm{~mm}$, respectively. 

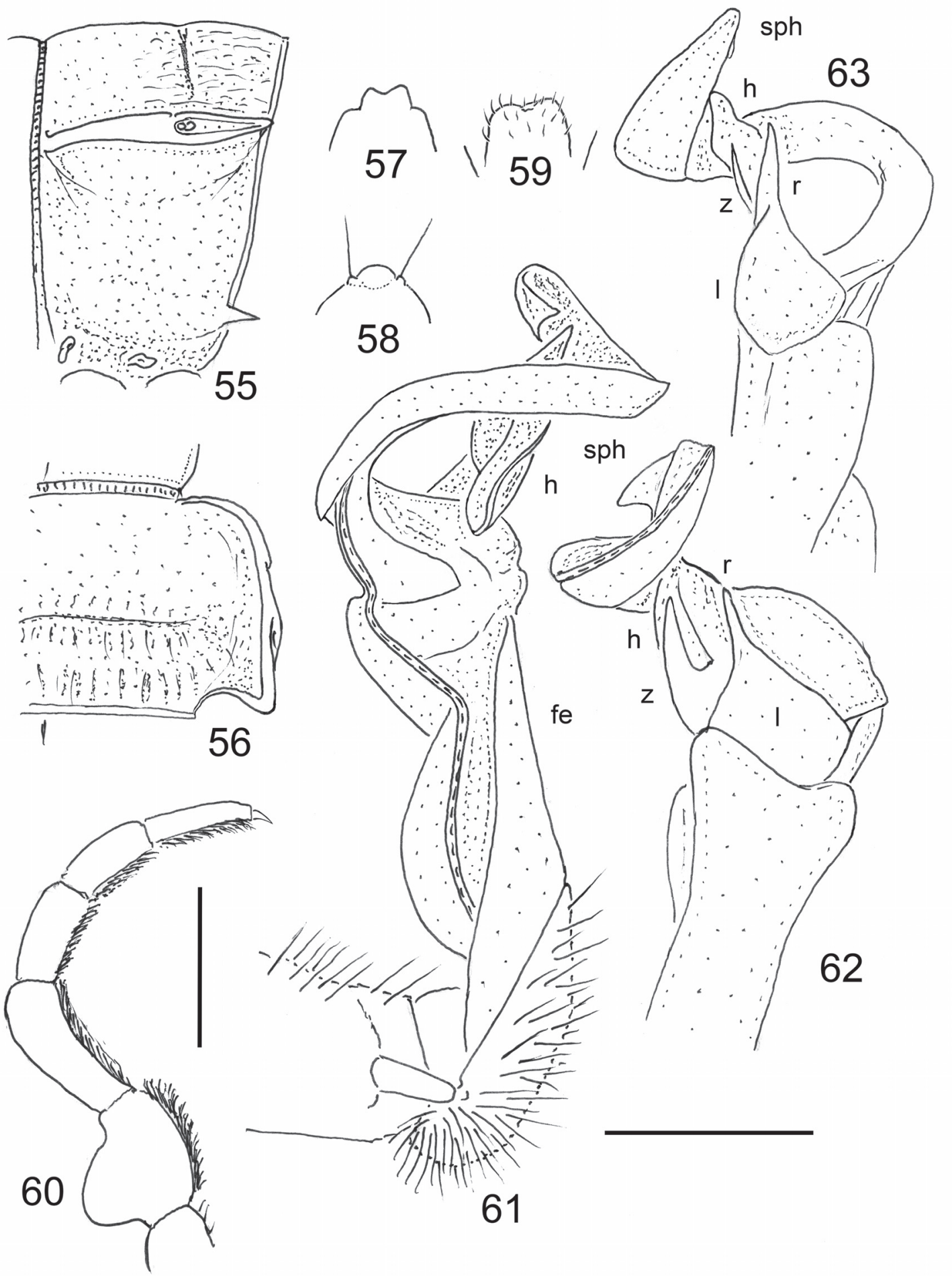

61

Figs 55-63. Tylopus jaegeri sp.n., O’ holotype. 55-56 - segment 9 and its right half, lateral and dorsal views, respectively; 57 epiproct, dorsal view; 58 - hypoproct, ventral view; 59 -sternal lobe between coxae 4, ventral view; 60 - leg 7, lateral view; 61-63 left gonopod, mesal, ventral and lateral views, respectively. Abbreviations: fe - femorite; $\mathbf{I}$ - postfemoral lateral lobe and its apical spine $\mathbf{r} ; \mathbf{s p h}$ - solenophore; $\mathbf{h}$ - basal process of solenophore; $\mathbf{z}$ - parabasal spine on $\mathbf{h}$. Scale bars: $1.0 \mathrm{~mm}(55-60)$ and $0.5 \mathrm{~mm}(61-63)$.

Рис. 55-63. Tylopus jaegeri sp.n., голотип О7. 55-56 - сегмент 9 и его правая половина, соответственно сбоку и сверху; 57 эпипрокт, сверху; 58 - гипопрокт, снизу; 59 - стернальная пластинка между тазиками 4, снизу; 60 - нога 7, сбоку; 61-63 левый гонопод, соответственно изнутри, снизу и сбоку. Сокращения: fe - феморит; $\mathbf{I}-$ постфеморальная боковая пластинка и его вершинный шип $\mathbf{r} ; \mathbf{s p h}-$ соленофор; $\mathbf{h}$ - базальный отросток соленофора; $\mathbf{z}$ - парабазальный шип на $\mathbf{h}$. Масштаб: 1,0 мм $(55-60)$ и 0,5 мм (61-63). 


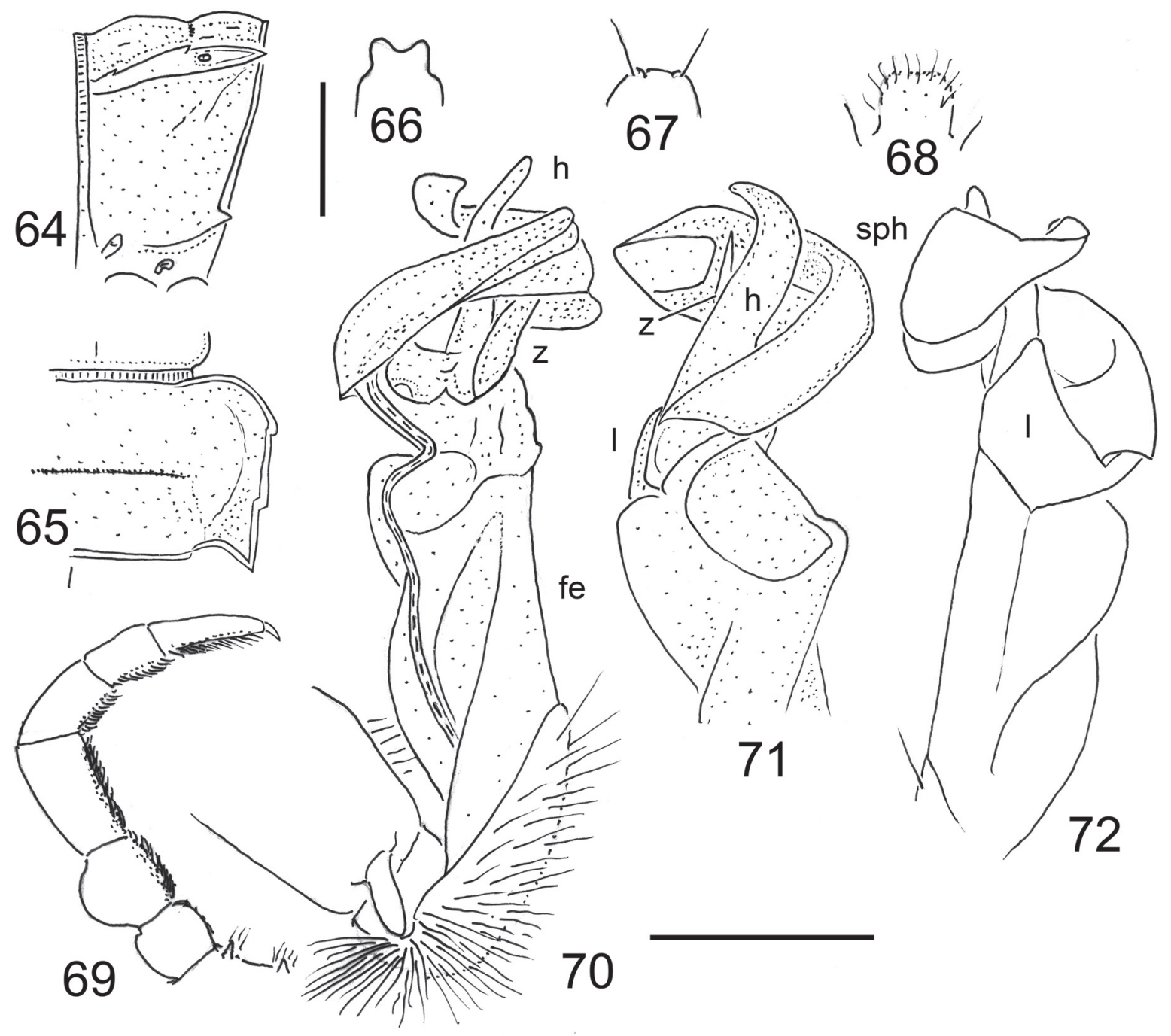

Figs 64-72. Tylopus altmannae sp.n., $\bigcirc^{7}$ holotype. 64-65 - segment 9 and its right half, lateral and dorsal views, respectively; $66-$ epiproct, dorsal view; 67 - hypoproct, ventral view; 68 - sternal lobe between coxae 4, ventral view; 69 - leg 7, lateral view; 70-72 left gonopod, mesal, ventral and lateral views, respectively. Abbreviations: fe - femorite and its gutter; $\mathbf{I}$ - postfemoral lateral lobe; sph solenophore; $\mathbf{h}$ - basal process of solenophore; $\mathbf{z}$ - parabasal spine on $\mathbf{h}$. Scale bars: $1.0 \mathrm{~mm}$ (64-69) and $0.5 \mathrm{~mm}$ (70-72).

Рис. 64-72. Tylopus altmannae sp.n., голотип О7. 64-65 - сегмент 9 и его правая половина, соответственно сбоку и сверху; 66 эпипрокт, сверху; 67 - гипопрокт, снизу; 68 - стернальная пластинка между тазиками 4, снизу; 69 - нога 7, сбоку; 70-72 левый гонопод, соответственно изнутри, снизу и сбоку. Сокращения: fe - феморит; $\mathbf{l}$ - постфеморальная боковая пластинка; sph соленофор; $\mathbf{h}$ - базальный отросток соленофора; $\mathbf{z}$ - парабазальный шип на $\mathbf{h}$. Масштаб: 1,0 мм (64-69) и 0,5 мм (70-72).

General coloration in alcohol light grey to grey-brown; head, collum and segments 2 and 3 , as well as strictures between pro- and metazonae infuscate, brown; antennae and legs light yellow; antennomere 7 contrasting dark brown. Paratype ca $19 \mathrm{~mm}$ long, creamy to pallid.

All other characters as above in T. jaegeri sp.n., except as follows.

Interantennal isthmus ca 0.6 as broad as diameter of antennal socket. Tegument smooth, shining, only in places faintly rugulose (Figs 64-65), below paraterga microgranulate. Caudal corner of paraterga drawn behind rear tergal margin in segments $2-7$ and $11-19$, mostly acute and pointed, especially long and spiniform in segments 16-19. Pleurosternal carinae with caudal teeth (Fig. 64) growing in- creasingly strong and long towards segment 7 , thereafter increasingly reduced towards segment 16 , only small bulges retained in segments 17 and 18 , totally suppressed in $19^{\text {th }}$. Hypoproct (Fig. 67) subtrapeziform. A short sternal spinicle near each coxa (Fig. 69).

Gonopod (Figs 70-72) rather complex; apical postfemoral lobe (I) subtriangular, but devoid of an apical spine. with a small spine (r) on top. Basal process $\mathbf{h}$ of solenophore (sph) longer and only faintly twisted, with a larger spiniform process $\mathbf{z}$ near $\mathbf{h}$ base.

REMARK. The type locality being a cave (= Tham) is certainly random, because this species shows no signs of troglomorphism whatsoever. 


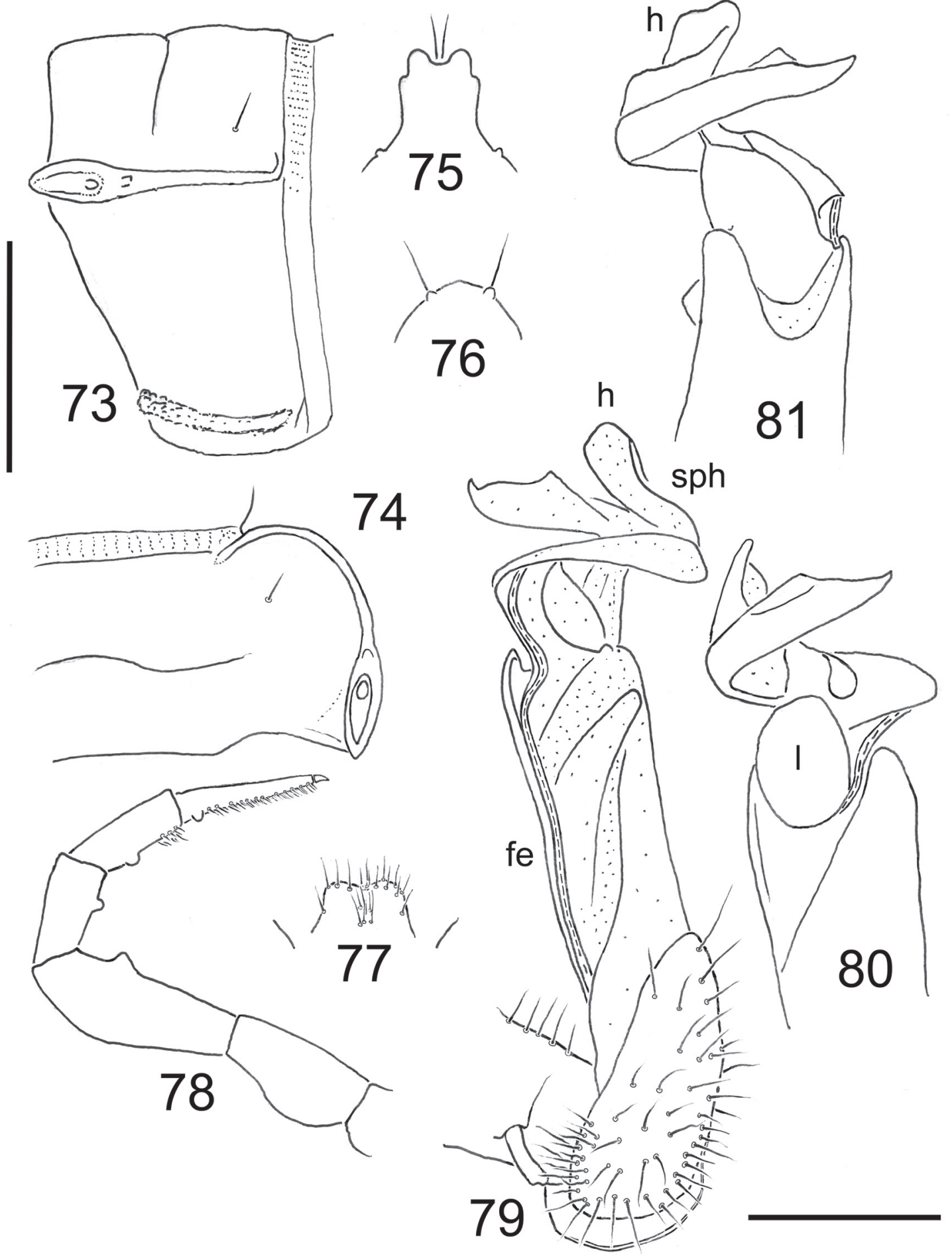

Figs 73-81. Tylopus nigromarginatus sp.n., $0^{7}$ holotype. 73-74 — segment 9 and its right half, lateral and dorsal views, respectively; 75 - epiproct, dorsal view; 76 - hypoproct, ventral view; 77 - sternal lobe between coxae 4, ventral view; 78 - leg 11, lateral view; 79-81 - left gonopod, mesal, ventral and lateral views, respectively. Abbreviations: fe - femorite and its gutter; $\mathbf{l}$ - postfemoral lateral lobe; sph - solenophore; $\mathbf{h}$ - basal process of solenophore. Scale bars: $1.0 \mathrm{~mm}$ (73-78) and 0.5 mm (79-81).

Рис. 73-81. Tylopus nigromarginatus sp.n., голотип О7. 73-74 - сегмент 9 и его правая половина, соответственно сбоку и сверху; 75 - эпипрокт, сверху; 76 - гипопрокт, снизу; 77 - стернальная пластинка между тазиками 4, снизу; 78 - нога 11 , сбоку; 79-81 - левый гонопод, соответственно изнутри, снизу и сбоку. Сокращения: $\mathbf{f e}-$ феморит; $\mathbf{l}-$ постфеморальная боковая пластинка; $\mathbf{s p h}$ - соленофор; $\mathbf{h}$ - базальный отросток соленофора. Масштаб: 1,0 мм (73-78) и 0,5 мм (79-81). 


\section{Tylopus nigromarginatus sp.n.} Figs 73-81.

HOLOTYPE $\sigma^{\text {T }}$ (SMF), China, Chongqing, Jinyunshan, N $29^{\circ} 50^{\prime} 26.07^{\prime \prime}$, E $106^{\circ} 23^{\prime} 26.09^{\prime \prime}, 836 \mathrm{~m}$ a.s.l., secondary forest, stump, trees, small cave, daytime, by hand, 12.X.2017, leg. P. Jäger.

NAME. To emphasize the very narrow, but contrasting blackish caudal margins of the collum and following metazonae.

DIAGNOSIS. Using the latest key to Tylopus species [Likhitrakarn et al., 2016b], also considering the species described since [Golovatch et al., 2016; Golovatch, Semenyuk, 2018] and herewith, T. nigromarginatus sp.n. keys out to couplet 6 , but fails to fit any particular species thereafter. It differs through a peculiar combination of characters such as no vivid colour pattern, well-developed paraterga and pleurosternal carinae, a generally smooth texture of the metaterga, considerably inflated $\sigma^{7}$ prefemora, the presence of adenostyles, an unusually strong and twisted basal process $\mathbf{h}$ of the solenophore etc.

DESCRIPTION. Holotype ca $28 \mathrm{~mm}$ long, width of midbody pro- and metazonae 2.7 and $3.8 \mathrm{~mm}$, respectively. General coloration in alcohol nearly completely pallid, only head light yellowish while collum and segments 2 and 3 light grey. Very narrow, but contrasting blackish caudal margins of the collum and following metazonae.

Clypeolabral region densely, vertigial one sparsely, setose; epicranial suture superficial. Antennae rather short and clavate, in situ slightly extending behind only to segment 3 when stretched dorsally $\left(O^{7}\right)$; antennomere $2=3>4>5=6$ $>1>7$; interantennal isthmus ca 0.6 times as broad as diameter of antennal socket.

Tegument mostly smooth and shining, only dorsal surfaces of metaterga in places striolate, prozonae microreticulate/microalveolate, sides below paraterga dull and microgranulate. In width, head $<<$ collum $=$ segment $3=4<2<$ $5-16$; thereafter body gradually tapering towards telson. Collum broadly and regularly rounded laterally, with one lateral setigerous incision/insertion point near midlength, caudal corner broadly and regularly rounded. Postcollum paraterga strongly developed, mostly set at about $1 / 3$ of body height (Figs 73-74), only slightly thicker on porebearing segments compared to poreless ones, largely subhorizontal to faintly upturned. Paraterga 2 drawn both anteriad and posteriad, caudal corner acute (at about $65^{\circ}$ ), unlike all following paraterga with four insertion points of setae at each lateral margin, thereafter with 1-2 very delicate, often barely visible, lateral, setigerous insertion points on a narrow callus. Pore-bearing paraterga with only one evident setigerous incision in anterior $1 / 3$ of a thicker callus, the latter sinuate and marking ozopore position (Fig. 73-74). Each callus completely set off by a sulcus both dorsally and ventrally, but ventral sulci more poorly developed than dorsal ones. Caudolateral corner narrowly rounded to subacuminate, but not really pointed (Figs 73-74), increasingly well drawn behind rear tergal margin in all segments, subspiniform and particularly long in segments 15-19. Ozopores dorsolateral, visible also from above, lying inside an ellipsoid groove at ca 1/3 off caudolateral corner (Figs 73-74). Collum with three transverse rows of short simple setae: $4+4,1+1$ and 2+2, all devoid of meaningful knobs/tubercles. Following metaterga with two transverse rows of similar, but mostly abraded setae, each seta ca $1 / 4-1 / 5$ as long as metatergum, setation pattern unclear due to often vague insertion points, but mostly apparently $2+2$ and $2+2$ or $3+3$ in each row. Transverse metatergal sulci evident, sinuate, almost reaching the bases of paraterga, present on segments $5-18$, absent from $19^{\text {th }}$. Stricture dividing pro- and metazonae rather broad and deep, very delicately striolate at bottom down to below paraterga. Pleurosternal carinae evident, arcuated, coarsely granulate ridges with an increasingly well developed, but blunt caudal tooth up to segment 7 , thereafter rather quickly reduced to segment 11 (Fig. 73). Axial line missing. Limbus simple. Epiproct conical, deeply emarginate at apex, subapical lateral papillae small (Fig. 75). Hypoproct (Fig. 76) semi-circular, caudal $1+1$ setae well-separated, borne on minute knobs.

Sterna very densely setose, with an evident, sharp, sternal cone near each coxa and a subtrapeziform, medially slightly hollow, setose lobe (Fig. 77) between coxae $4\left(\sigma^{7}\right)$; cross-impressions moderate, transverse impressions a little deeper than axial ones. Prefemora inflated laterad $\left(O^{7}\right)$, adenostyles mostly small, but one tubercle present on each acropoditomere, pattern as in Fig. 78. Legs long (Fig. 78), apparently crassate compared to + , ca $1.7-1.8$ times as long as midbody height $\left(O^{7}\right)$; in length, femora $>$ prefemora $=$ tarsi $>$ postfemora $=$ tibiae $>$ coxae; claw simple, slightly curved ventrad. All podomeres densely setose ventrally up to last two pairs, tarsi with particularly dense ventral brushes (Fig. 78).

Gonopods (Figs 79-81) rather complex; coxite much shorter than telopodite, subcylindrical, setose distoventrally; "prefemoral" (= densely setose) part of telopodite almost as long as a parallel-sided femorite (fe), the latter with a distinct mesal gutter/excavation and set off from a postfemoral part by a distinct cingulum demarcating, on lateral side, an ovoid apical lobe (I). A long, coiled, slender, subacuminate solenophore (sph) twisted around a long, prominent, helicoid, acuminate, basal process $\mathbf{h}$ devoid of remarable outgrowths; tip of solenomere not exposed beyond sph.

ACKNOWLEDGEMENTS. I am most grateful to the administration of the Senckenberg Museum, Frankfurt/M., Germany for the financial support rendered, through the activities of Peter Jäger, the keeper, and Julia Altmann, his assistant, to make my visit to the SMF possible in JulyAugust 2018. Selvin Dashdamirov (Düsseldorf, Germany) very generously offered me his technical assistance. Kirill Mikhailov (ZMUM) kindly helped me incorporate the few samples shared with the ZMUM into the collection under his care.

\section{References}

Chen C.C., Golovatch S.I., Chang H.W. 2008. Identity of the east Asian millipede Habrodesmus inexpectatus Attems, 1944 (Diplopoda: Polydesmida: Paradoxosomatidae) // Journal of Natural History. Vol.42. Nos 39-40. P.2547-2556.

Chen C.C., Golovatch S.I., Mikhaljova E.V., Chang H.W. 2010. The millipede genus Anoplodesmus Pocock, 1895, recorded in Taiwan for the first time, with descriptions of two new species (Diplopoda: Polydesmida: Paradoxosomatidae: Sulciferini) // Zootaxa. Vol.2399. P.20-30.

Decker P., Tertilt T. 2012. First records of two introduced millipedes Anoplopodesmus saussurii and Chondromorpha xanthotricha (Diplopoda: Polydesmida: Paradoxosomatidae) in Singapore // Nature in Singapore. Vol.5. P.141-149.

Golovatch S.I. 2013. On several new or poorly-known Oriental Paradoxosomatidae (Diplopoda: Polydesmida), XIII // Arthropoda Selecta. Vol.22. No.1. P.1-31. 
Golovatch S.I. 2016. On several new or poorly-known Oriental Paradoxosomatidae (Diplopoda: Polydesmida), XIX // Arthropoda Selecta. Vol.25. No.2. P.131-152.

Golovatch S.I., Enghoff H. 1994. Review of the dragon millipedes, genus Desmoxytes Chamberlin, 1923 (Diplopoda, Polydesmida, Paradoxosomatidae) // Steenstrupia. Vol.20. No.2. P.45-71.

Golovatch S.I., Semenyuk I.I. 2018. On several new or poorlyknown Oriental Paradoxosomatidae (Diplopoda: Polydesmida), XXIV // Arthropoda Selecta. Vol.27. No.3. P.187-200.

Golovatch S.I., VandenSpiegel D., Semenyuk I.I. 2016. On several new or poorly-known Oriental Paradoxosomatidae (Diplopoda: Polydesmida), XXI // Arthropoda Selecta. Vol.25. No.4. P.335-354.

Likhitrakarn N., Golovatch S.I., Panha S. 2016a. Review of the Southeast Asian millipede genus Antheromorpha Jeekel, 1968 (Diplopoda, Polydesmida, Paradoxosomatidae) // ZooKeys. Vol.571. P.21-57.

Likhitrakarn N., Golovatch S.I., Panha S. 2016b. The millipede genus Tylopus Jeekel, 1968 (Diplopoda, Polydesmida, Para- doxosomatidae), with a key and descriptions of eight new species from Indochina // European Journal of Taxonomy. Vol.195. P.1-47.

Nguyen D.A., Nguyen S.G., Le S.X. 2018. On the millipede genus Antheromorpha Jeekel, 1968 (Diplopoda: Polydesmida: Paradoxosomatidae) from Vietnam, with a description of a new species // The Raffles Bulletin of Zoology. Vol.66. P.96-109.

Srisonchai R., Enghoff H., Likhitrakarn N., Panha S. 2018a. A revision of dragon millipedes I: genus Desmoxytes Chamberlin, 1923, with the description of eight new species (Diplopoda, Polydesmida, Paradoxosomatidae) // ZooKeys. Vol.761. P.1-177.

Srisonchai R., Enghoff H., Likhitrakarn N., Panha S. 2018b. A revision of dragon millipedes IV: the new genus Spinaxytes, with the description of nine new species (Diplopoda, Polydesmida, Paradoxosomatidae) // ZooKeys. Vol.797. P.19-69.

Responsible editor K.G. Mikhailov 